\title{
ANALISA BEBERAPA FAKTOR YANG MEMPENGARUHI PENYALURAN DANA MODAL KERJA PADA PT. BANK MANDIRI SYARIAH INDONESIA, TBK CABANG PALEMBANG Yunidar Erlina ${ }^{1}$, Ernawati ${ }^{2}$, Kamariah ${ }^{3}$ \\ 1,3 Dosen jurusan Manajemen, Universitas Tridinanti, Sumatera Selatan \\ 2. Dosen jurusan Akuntansi, Universitas Tridinanti, Sumatera Selatan \\ Email : 1)yunidarerlina21@gmail.com ${ }^{2)}$ ernalukman59@gmail.com ${ }^{3}{ }^{3}$ iyasdanial58@gmail.com
}

\section{Submitted: \\ $05 / 12 / 2021$ \\ Revised: \\ $20 / 12 / 2021$ \\ Accepted: \\ $25 / 12 / 2021$ \\ Online-Published: \\ $31 / 12 / 2021$}

INFORMASI ARTIKEL

\begin{abstract}
ABSTRAK
Pembiayaan Modal Kerja adalah salah satu produk yang dimiliki Bank Mandiri Syariah Indonesia yang akan membantu kebutuhan modal kerja usaha sehingga kelancaran operasional dan rencana pengembangan usaha akan terjamin. Berdasarkan prinsip syariah dengan pilihan akad musyarakah, mudharabah, murabahah dan ijarah muntahiya bit tamlik sesuai dengan spesifikasi kebutuhan modal kerja. Dalam pencapaian target keuntungan yang diperoleh bank Mandiri Syariah yaitu dengan mengeluarkan biaya tinggi dan dengan biaya tinggi tersebut diharapkan akan mendapatkan hasil yang maksimal. Permasalah yang akan dikaji dalam penelitian ini adalah sejauh mana pengaruh beberapa factor terhadap penyaluran dana modal kerja pada PT. Bank Mandiri Syariah Palembang

Tehnik pengumpulan data menggunakan hasil wawancara, catatan lapangan, dan bahan-bahan lain, Teknik pengelolaan data gunakan adalah dari hasil wawancara, observasi, dokumentasi, dan bahan pustaka dengan menggunakan pola deskriptif analisis, Dari hasil penelitian diperoleh Besarnya pengaruh ukuran perusahaan terhadap penyaluran dana modal kerja sebesar 0,05 atau 0,5\%. Pengaruh ini jika dilihat adalah kecil, hal ini menunjukkan bahwa ukuran perusahaan dalam menyalurkan dana modal kerja akan turun sebesar 0,5\%. Atau naik sebesar 0,5\%. Begitu pula sebaliknya, korelasi X2 terhadap Y (Perputaran persediaan terhadap penyaluran dana modal kerja), hal ini dapat dilihat dari hasil olahan data SPSS 24.0 for windows Hasil penelitian diperolah persamaan regresi sederhana daptat diketahui bahwa beberapa factor memiliki pengaruh yang besar ( positif ) pada pembiayaan Modal Kerja.
\end{abstract}

Kata kunci: Bank Syariah, Pembiayaan Modal Kerja. 


\section{A. PENDAHULUAN}

Sejalan dengan perkembangan perekonomian dan kemajuan teknologi peranan dunia perbankan sangat penting dalam menunjang pembangunan di Indonesia, sebab bank merupakan lembaga keuangan yang menjadi tempat bagi perusahaan, badan-badan pemerintahan baik swasta maupun perorangan untuk menyimpan aset dan dananya melalui kegiatan simpan-pinjam dari berbagai produk maupun jasa yang diberikan oleh bank, sesuai dengan fungsi bank yaitu melayani kebutuhan masyarakat serta melancarkan mekanisme sistem pembayaran bagi sektor perekonomian dunia.

Bank Syariah adalah bank yang aktivitasnya meninggalkan masalah riba. Dengan demikian penghindaran bunga yang dianggap riba merupakan salah satu tantangan yang dihadapi dunia Islam saat ini. Para ekonom muslim telah mencurahkan perhatian besar guna menemukan cara untuk menggantikan sistem bunga dalam transaksi perbankan dan keuangan yang lebih sesuai dengan syariah Islam. Oleh karena itu, mekanisme perbankan bebas bunga yang biasa disebut dengan Bank Syariah didirikan. Perbankan syariah didirikan didasarkan pada alasan filosofis maupun praktik.

Alasan filosofinya adalah dilarangnya riba dalam transaksi keuangan maupun non keuangan [...Allah menghalalkan jual beli dan mengharamkan riba...(QS. Al-Baqarah (2:275)] dan alasan praktiknya adalah sistem perbankan berbasis bunga atau konvensional mengandung beberapa kelemahan (menurut Zainul Arifin, 2002: 39), yaitu sebagai berikut:

1. Transaksi berbasis bunga
melanggar keadilan atau
kewajaran bisnis.

2. Tidak fleksibelnya sistem transaksi berbasis bunga menyebabkan kebangkrutan.

3. Komitmen bank untuk keamanan uang deposan berikut bunganya membuat bank cemas untuk mengembalikan pokok dan bunganya.

4. Sistem transaksi berbasis bunga menghalangi munculnya inovasi oleh usaha kecil.

5. Dalam sistem bunga, bank tidak akan tertarik dalam kemitraan usaha kecuali bila ada jaminan kepastian pengembalian modal dan pendapatan bunga mereka.

Adapun produk pembiayaan yang ditawarkan oleh PT. Bank Mandiri Indonesia, Tbk salah satunya adalah Pembiayaan Modal Kerja, yang bisa dibiayai oleh pembiayaan ini antara lain usaha pertanian seperti perkebunan, kelapa sawit, karet, kopi dan sebagainya. Perdagangan seperti grosiran, mini market dan lain-lain. Industri Kecil meliputi usaha perabotan. Industri Makanan, seperti usaha tempe, tahu. Usaha perbengkelan, dan banyak lagi usaha kecil dan menengah yang bisa dibiayai oleh fasilitas kredit ini asalkan usaha tersebut tidak bertentangan dengan peraturan yang telah ditetapkan .

Islam sebagai agama yang universal dan komprehensip, universal berarti Islam diperuntukkan bagi seluruh umat manusia dimuka bumi dan dapat diterapkan dalam setiap waktu dan tempat sampai akhir zaman. Sebagai ajaran yang komprehensip Islam meliputi tiga pokok ajaran yaitu akidah, syariah dan akhlak.

Sebagaimana firman Allah dalam surat Al-Jumu'ah ayat 10 :

Artinya : "Maka bertebaranlah kamu dimuka bumi, dan carilah karunia Allah 
dan ingatlah sebanyak-banyaknya supaya kamu beruntung. "(Al-Jumu'ah, Ayat:10)

Kredit dalam ekonomi Islam dikenal dengan pembiayaan, menurut undang-undang Nomor 10 Tahun 1998. Pembiayaan adalah penyediaan uang atau tagihan yang dapat dipersamakan dengan itu, berdasarkan persetujuan atau kesepakatan antara bank dan pihak lain yang mewajibkan pihak yang dibiayai untuk mengembalikan uang atau tagihan tersebut setelah jangka waktu tertentu dengan imbalan atau bagi hasil. Dari uraian diatas, penulis bermaksud meneliti lebih lanjut mengenai Pembiayaan Modal Kerja beserta aspek-aspek yang terkait di dalamnya, dengan judul dalah "Analisa Beberapa Faktor Yang Mempengaruhi Penyaluran Dana Modal Kerja Di PT. Bank Mandiri Indonesia Tbk Cabang Palembang".

\section{Perumusan Masalah}

1. Apakah ukuran (size) perusahaan berpengaruh terhadap penyaluran dana modal kerja pada PT. Bank Mandiri Indonesia Tbk Cabang Palembang?

2. Apakah perputaran persediaan berpengaruh terhadap penyaluran dana modal kerja pada PT. Bank Mandiri Indonesia Tbk Cabang Palembang ?

3. Apakah perputaran piutang berpengaruh terhadap penyaluran dana modal kerja pada PT. Bank Mandiri Indonesia Tbk Cabang Palembang ?

4. Apakah ukuran perusahaan, perputaran persediaan dan perputaran piutang berpengaruh secara bersama-sama terhadap penyaluran dana modal kerja pada PT. Bank Mandiri Indonesia Tbk Cabang Palembang?

\section{B. METODE PENELITIAN}

\section{Tempat dan Waktu Penelitian}

Penelitian ini dilakukan pada PT. Bank Mandiri Syariah Indonesia, Tbk Kantor Cabang Palembang yang berlokasi di Jl A. Rivai Palembang. Waktu Penelitian bulan Mei 2021 sampai dengan Oktober 2021.

\section{Sumber Data Teknik Pengumpulan Data}

a. Data Primer yaitu data-data yang diperoleh secara langsung dari responden penelitian dalam bentuk wawancara yang didapat dari Asset Division (PDD).

b. Data Sekunder

\section{Teknik Pengumpulan Data}

a. Reduksi data: Mereduksi data berarti merangkum, memilih hal-hal yang pokok, memfokuskan pada hal-hal yang penting, dicari tema dan polanya.

b. Penyajian data: langkah selanjutnya adalah mendisplaykan data dalam bentuk naratif yang bersifat deskriptif Selain itu juga penulis menyajikan dalam bentuk tabel dan gambar, sehingga tujuan dari penelitian ini dapat terjawab.

c. Penarikan kesimpulan atau verifikasi: Pada tahap akhir, data yang tersaji harus dapat menjawab rumusan masalah yang dirumuskan sejak awal. Sehingga memperoleh kesimpulan mengenai produk murabahah pada Pembiayaan Hunian Syariah Bank Mandiri Indonesia serta faktor-faktor yang mempengaruhi pembiayaan hunian syariah tersebut.

\section{Populasi, Sampel, dan Sampling}

\section{Populasi}

Populasi penelitian ini 45 0rang karyawan penyaluran dana modal kerja pada PT. Bank Mandiri Indonesia yang 
terlibat dalam penyaluran dana modal kerja

\section{Sample}

Sampel penelitian ini 45 Orang karyawan penyaluran dana modal kerja pada PT. Bank Mandiri Indonesia yang terlibat dalam penyaluran dana modal kerja

\section{Sampling}

Teknik purvosive sampling dengan pertimbangan adanya kemudahan untuk mendapatkan data penyebaran kuesioner kepada seluruh responden.

\section{Rancang Penelitian}

\begin{tabular}{|c|c|c|c|}
\hline Variabel & Definisi & Indikator & $\begin{array}{l}\text { Skala } \\
\text { Ukur }\end{array}$ \\
\hline $\begin{array}{l}\text { Ukuran } \\
\text { perusahaan }(\mathrm{X} 1)\end{array}$ & $\begin{array}{l}\text { Pengelompokan } \\
\text { perusahaan kedalam } \\
\text { beberapa kelompok } \\
\text { yaitu besar, sedang } \\
\text { dan kecil (Siswanto, } \\
\text { 2009). }\end{array}$ & $\begin{array}{l}\text { Total asset } \\
\text { Total Penjualan } \\
\text { Kebijakan akuntansi } \\
\text { yang digunakan }\end{array}$ & Ordinal \\
\hline $\begin{array}{l}\text { Perputaran } \\
\text { persediaan (X2) }\end{array}$ & $\begin{array}{l}\text { Jumlah harga pokok } \\
\text { barang yang dijual } \\
\text { atau rata-rata } \\
\text { persediaan yang } \\
\text { dimiliki perusahaan } \\
\text { (Munawir, 2010). }\end{array}$ & $\begin{array}{l}\text { Pengelolaan } \\
\text { perusahaan } \\
\text { Kecepatan dan } \\
\text { pergantian persediaan } \\
\text { Persediaan yang } \\
\text { diproduksi cepat } \\
\text { Biaya penyimpanan } \\
\text { rendak } \\
\text { Kerusakan rendah }\end{array}$ & Ordinal \\
\hline $\begin{array}{l}\text { Perputaran } \\
\text { Piutang (X3) }\end{array}$ & $\begin{array}{l}\text { Berapa kali suatu } \\
\text { perusahaan menagih } \\
\text { piutangnya dalam } \\
\text { satu periode, hal ini } \\
\text { menujukan efisiensi } \\
\text { pengelolaan piutang } \\
\text { (Soemarso, 2010). }\end{array}$ & $\begin{array}{l}\text { Tingkat pengelolaan } \\
\text { piutang } \\
\text { Kebijakan penjualan } \\
\text { kredit } \\
\text { Keefcektifan piutang }\end{array}$ & Ordinal \\
\hline $\begin{array}{ll}\text { Penyaluran } & \text { dana } \\
\text { modal kerja } & (\mathrm{Y})\end{array}$ & $\begin{array}{lr}\text { Pemberian } & \text { uang } \\
\text { secara langsung yang } \\
\text { akan } & \text { digunakan } \\
\text { untuk penambahan } \\
\text { modal } \\
\text { (Siswanto, 2009). }\end{array}$ & $\begin{array}{l}\text { Karakter } \\
\text { Kemampuan } \\
\text { Kondisi } \\
\text { Modal } \\
\text { Jaminan }\end{array}$ & Ordinal \\
\hline
\end{tabular}

http://www.univ-tridinanti.ac.id/ejournal/index.php/ratri adalah rancangan deskriptif analisis ,penelitian deskriptif analisis bertujuan untuk mengumpulkan informasi aktual secara rinci yang melukiskan gejala yang ada, mengidentifikasi masalah atau memberikan kondisi dan praktek-praktek yang berlaku, membuat perbandingan dan evaluasi, menentukan apa yang dilakukan orang lain dalam menghadapi masalah yang sama dan belajar dari pengalaman mereka untuk menetapkan rancangan dan keputusan pada waktu yang akan datang.

\section{Variabel dan Definisi Operasional}

Tabel 1. Variabel dan Definisi Opersional 


\section{Hipotesis}

Hipotesis pertama

$\mathrm{H}_{0}: \mathrm{b}_{1}$ Tidak terdapat pengaruh atau $b_{2}=$ positif dan signifikan $0 \quad$ Ukuran perusahaan $\left(\mathrm{X}_{1}\right)$ dan Perputaran persediaan $\left(\mathrm{X}_{2}\right) \quad$ serta Perputaran piutang (X3) secara simultan terhadap Penyaluran dana modal kerja (Y) di PT. Bank Mandiri Syariah Indonesia Tbk Cabang Palembang.

$\mathrm{H}_{1}$ : $\mathrm{b}_{1}$ Terdapat pengaruh positif atau $b_{2} \neq$ dan signifikan Ukuran 0 perusahaan $\left(\mathrm{X}_{1}\right)$ dan Perputaran persediaan $\left(\mathrm{X}_{2}\right)$ serta Perputaran piutang (X3) secara simultan terhadap Penyaluran dana modal kerja (Y) di PT. Bank Mandiri Indonesia Tbk Cabang Palembang .

Hipotesis kedua

$$
\begin{aligned}
\mathrm{H}_{0}: \mathrm{b}_{1}= & \text { Tidak terdapat pengaruh } \\
0 & \text { positif dan signifikan } \\
& \text { Ukuran perusahaan }\left(\mathrm{X}_{1}\right) \\
& \text { terhadap Penyaluran } \\
& \text { dana modal kerja (Y) di } \\
& \text { PT. Bank Mandiri } \\
& \text { Syariah Indonesia Tbk } \\
& \text { Cabang Palembang. } \\
\mathrm{H}_{1}: \mathrm{b}_{1} \neq & \text { Terdapat pengaruh } \\
0 & \text { positif dan signifikan } \\
& \text { Ukuran perusahaan (X1) } \\
& \text { terhadap Penyaluran } \\
& \text { dana modal kerja (Y) di } \\
& \text { PT. Bank Mandiri } \\
& \text { Syariah Indonesia Tbk } \\
& \text { Cabang Palembang. }
\end{aligned}
$$

Hipotesis Ketiga

$\mathrm{H}_{0}: b_{1}$ Tidak terdapat pengaruh $=0$ positif dan signifikan Perputaran piutang (X3) terhadap Penyaluran dana modal kerja (Y) di PT.
Bank Mandiri syariah Indonesia Tbk Cabang Palembang.

$\mathrm{H}_{1}: \mathrm{b}_{1} \quad$ Terdapat pengaruh positif $\neq 0$ dan signifikan Perputaran piutang (X3) terhadap Penyaluran dana modal kerja (Y) di PT. Bank Mandiri Syariah Indonesia Tbk Cabang Palembang .

\section{HASIL DAN PEMBAHASAN Uji Validitas}

Teknik yang dilakukan yaitu dengan metode Pearson correlation .Dari hasil perhitungan Pearson correlation nomor pertanyaan yang memiliki jumlah bendera (flag) atau tanda bintang hanya 1 (*) berarti pertanyaan valid pada $\alpha=0,05$, dan tanda bintang $2(* *)$ valid ada $\alpha=0,01$.

Pada hasil olahan data menunjukkan hasil uji validitas terhadap populasi 24 karyawan untuk ukuran perusahaan $\left(\mathrm{X}_{1}\right)$, perputaran persediaan $\left(\mathrm{X}_{2}\right)$ dan Perputaran piutang (X3) terhadap penyaluran dana modal kerja (Y). Menunjukkan valid dimana signifikansinya lebih kecil dari alpa $(0,05)$.

Berdasarkan hasil uji validitas variabel perputaran persediaan (X2), Perputaran piutang (X3) dan penyaluran dana modal kerja (Y) pada lampiran hasil olahan data dapat disimpulkan hampir seluruh butir item pertanyaan dinyatakan valid. Pengertian secara umum bahwa sebuah item (pertanyaan) dinyatakan valid jika mempunyai dukungan yang kuat terhadap skor total, dimana nilai pada out put SPSS nilai Sig (2-tailed) antara setiap butir pertanyaan dari masing-masing pertanyaan lebih kecil dari $\alpha=5 \%$ (tingkat kepercyaan 95\%) atau nilai korelasi pada setiap butir pertanyaan di atas ditandai dengan $(*)$ atau $(* *)$. 


\section{Uji Reliabilitas}

Nilai alpha cronbach yang lebih besar dari 0,6 maka dapat dinyatakan reliabel. Hasil uji ini bisa dilihat pada hasil olahan data out put SPSS pada lampiran dan dapat dilihat pada table berikut :

\begin{tabular}{|c|c|c|c|}
\hline Variabel & $\begin{array}{c}\text { Nilai Alpha } \\
\text { Cronbach }\end{array}$ & N Of Items & Keterangan \\
\hline $\begin{array}{c}\text { Ukuran perusahaan } \\
\left(\mathrm{X}_{1}\right)\end{array}$ & 0,742 & 12 & Reliabel \\
\hline $\begin{array}{c}\text { Perputaran persediaan } \\
\left(\mathrm{X}_{2}\right)\end{array}$ & 0,658 & 10 & Reliabel \\
\hline $\begin{array}{c}\text { Perputaran piutang } \\
(\mathrm{X} 3)\end{array}$ & 0,606 & 12 & Reliabel \\
\hline $\begin{array}{c}\text { Penyaluran dana } \\
\text { modal kerja (Y) }\end{array}$ & 0,635 & 14 & \\
\hline
\end{tabular}

Sumber : Hasil uji reliabilitas diolah dari lampiran

Berdasarkan tabel 2 tersebut diatas, dapat dilihat bahwa nilai alpa cronbach lebih besar dari 0,6. Ini artinya bahwa pertanyaan valid juga reliabel. Atau nilai butir pertanyaan valid juga reliabel yang dapat dilihat pada hasil olahan cronbach alpa pada lampiran olahan data.
Tabel 2 Hasil Uji Reliabilitas Variabel ukuran perusahaan $\left(X_{1}\right)$, Perputaran persediaan (X2), Perputaran piutang (X3) dan penyaluran dana modal kerja (Y)

\begin{tabular}{|c|c|c|c|c|c|}
\hline & & $\begin{array}{c}\text { Ukuran } \\
\text { Perusahaan }\end{array}$ & $\begin{array}{l}\text { Perputaran } \\
\text { persediaan }\end{array}$ & $\begin{array}{l}\text { Perputaran } \\
\text { piutang }\end{array}$ & $\begin{array}{c}\text { Penyaluran } \\
\text { dana modal } \\
\text { kerja }\end{array}$ \\
\hline \multirow[t]{2}{*}{$N$} & Valid & 24 & 24 & 24 & 24 \\
\hline & Missing & 0 & 0 & 0 & 0 \\
\hline \multicolumn{2}{|c|}{ Mean } & 40.96 & 29.29 & 36.25 & 28.63 \\
\hline \multicolumn{2}{|c|}{ Median } & 43.00 & 29.50 & 36.00 & 29.00 \\
\hline \multicolumn{2}{|c|}{ Mode } & 44 & 25 & 36 & 29 \\
\hline \multicolumn{2}{|c|}{ Std. Deviation } & 4.525 & 3.329 & 2.878 & 3.487 \\
\hline \multicolumn{2}{|c|}{ Variance } & 20.476 & 11.085 & 8.283 & 12.158 \\
\hline \multicolumn{2}{|c|}{ Skewness } & -1.331 & -.086 & -1.574 & .028 \\
\hline \multicolumn{2}{|c|}{ Std. Error of Skewness } & .472 & .472 & .472 & .472 \\
\hline \multicolumn{2}{|c|}{ Kurtosis } & .757 & -1.395 & 3.805 & -.721 \\
\hline \multicolumn{2}{|c|}{ Std. Error of Kurtosis } & .918 & .918 & .918 & .918 \\
\hline \multicolumn{2}{|c|}{ Minimum } & $\underline{30}$ & 24 & $\underline{27}$ & $\underline{22}$ \\
\hline & $\underline{45}$ & 34 & $\underline{40}$ & 35 \\
\hline
\end{tabular}

Sumber : Diolah dengan SPSS Versi 24.00 pada lampiran. 


\section{Uji Persyaratan Analisis}

Uji Normalitas

Tabel 4 Rangkuman hasil uji normalitas

\begin{tabular}{|l|l|l|l|l|}
\hline No & Variabel & $\begin{array}{l}\text { Nilai Asymsig (2 } \\
\text { tailed) }\end{array}$ & Alpa =0,05 & Kesimpulan \\
\hline 1 & Ukuran perusahaan (X1) & 0,214 & 0,05 & Normal \\
\hline 2 & $\begin{array}{l}\text { Perputaran persediaan } \\
\text { X2) }\end{array}$ & 0,810 & 0,05 & Normal \\
\hline 3 & Perputaran piutang (X3). & 0,215 & 0,05 & Normal \\
\hline 4 & $\begin{array}{l}\text { Penyaluran dana modal } \\
\text { kerja (Y) }\end{array}$ & 0,855 & 0,05 & Normal \\
\hline
\end{tabular}

Sumber : Hasil olahan data melaui spss versi

24,00, lampiran.

\section{Uji homogenitas}

\section{Tabel 5. Rangkuman hasil uji}

\section{homogenitas}

\begin{tabular}{|l|l|l|l|l|}
\hline No & Variabel & $\begin{array}{l}\text { Nilai Asymsig (2 } \\
\text { tailed) }\end{array}$ & Alpa =0,05 & Kesimpulan \\
\hline 1 & Ukuran perusahaan (X1) & 0,243 & 0,05 & Homogen \\
\hline 2 & $\begin{array}{l}\text { Perputaran persediaan } \\
(\mathrm{X} 2)\end{array}$ & 0,967 & 0,05 & Homogen \\
\hline 3 & Perputaran piutang (X3). & 0,232 & 0,05 & Homogen \\
\hline 4 & $\begin{array}{l}\text { Penyaluran dana modal } \\
\text { kerja (Y) }\end{array}$ & 0.71 & 0.05 & Homogen \\
\hline
\end{tabular}

Sumber : Hasil olahan data melaui spss versi

24,00, lampiran

\section{Analisi Regresi linier berganda}

\section{Uji Linearitas}

Apabila nilai signifikansi yang digunakan untuk menolak atau menerima Ho, maka nilai koefisien harus dibandingkan dengan tingkat alpa=0.05. Kesimpulan yang harus diambil yaitu model regresi berbentuk linear, diterima jika signifikansi dari deviation from linierity > dari alpa $=0,05$ sebaliknya tidak linier jika kurang dari alpa. Untuk lineairty ketiga variabel tersebut adalah 0 , 27 dan 0,42, dan 0,61 lebih besar dari alpa $(0,05)$.

\begin{tabular}{|l|r|r|r|r|}
\multicolumn{5}{|c|}{ Model Summary } \\
\hline Model & $\mathrm{R}$ & \multicolumn{1}{c|}{$\mathrm{R}$ Square } & \multicolumn{1}{c|}{$\begin{array}{c}\text { Adjusted } \mathrm{R} \\
\text { Square }\end{array}$} & \multicolumn{1}{c|}{ Std. Error of the Estimate } \\
\hline 1 & $.447^{\mathrm{a}}$ & .200 & .080 & 3.345 \\
\hline
\end{tabular}

a. Predictors: (Constant), ukuran perusahaan, Perputaran persediaan, Perputaran piutang

Dari table tersebut di atas terlihat bahwa R square yang besarnya 0.200 .
Atas dasar hasil analisis penelitian yang telah dilakukan pada out put SPSS dapat dilihat pada table berikut ini :

Tabel 6 Pengaruh secara simultan (bersama-sama) Variabel ukuran perusahaan $\left(X_{1}\right)$, Perputaran persediaan $\left(\mathbf{X}_{2}\right)$, Perputaran piutang (X3) terhadap penyaluran dana modal kerja 
variable lain yang tidak diteliti pada penelitian ini.

Kondisi ini memperlihatkan bahwa ukuran perusahaan, perputaran persediaan dan Perputaran piutang secara bersama-sama dapat berpengaruh terhadap penyaluran dana modal kerja sebesar 20\%, sisanya dipengaruhi oleh variabel lain yang tidak diteliti pada penelitian ini. Pengaruh secara bersama dapat dari hasil out put SPSS yaitu seperti pada table 7 berikut;

Tabel 7 Coeficient (model regresi berganda).

\begin{tabular}{|c|c|c|c|c|c|c|}
\hline \multirow{2}{*}{\multicolumn{2}{|c|}{ Model }} & \multicolumn{2}{|c|}{ Unstandardized Coefficients } & \multirow{2}{*}{$\begin{array}{c}\begin{array}{c}\text { Standardized } \\
\text { Coefficients }\end{array} \\
\text { Beta }\end{array}$} & \multirow[b]{2}{*}{$\mathrm{t}$} & \multirow[b]{2}{*}{ Sig. } \\
\hline & & $\mathrm{B}$ & Std. Error & & & \\
\hline \multirow[t]{4}{*}{1} & (Constant) & 54.003 & 12.847 & & 4.203 & .000 \\
\hline & $\begin{array}{l}\text { Ukuran } \\
\text { perusahaan }\end{array}$ & -.497 & .243 & -.410 & -2.046 & .054 \\
\hline & $\begin{array}{l}\text { Perputaran } \\
\text { persediaan }\end{array}$ & -.152 & .214 & -.145 & -.709 & .486 \\
\hline & $\begin{array}{l}\text { Perputaran } \\
\text { piutang }\end{array}$ & -.072 & .157 & -.093 & -.455 & .654 \\
\hline
\end{tabular}

a. Dependent Variable: penyaluran dana

Dari table 7 di atas persamaan regresi linear berganda adalah $\mathrm{Y}=54.003$ - 0,497 $\mathrm{X}_{1}-0,152 \mathrm{X}_{2}-0,072 \mathrm{X} 3+\mathrm{e}$. dapat diartikan bahwa apabila terjadi kenaikan nilai ukuran perusahaan $\left(\mathrm{X}_{1}\right)$, Perputaran persediaan $\left(\mathrm{X}_{2}\right)$, dan Perputaran piutang (X3) maka akan mengalami penurunan sebesar 54.003 satuan.

\section{Koefisien Korelasi (r)}

Model Summary Program SPSS

Versi 24.00 diketahui bahwa koefisien korelasi berganda antara $\mathrm{X}_{1}, \mathrm{X}_{2}$ dan $\mathrm{x} 3$ terhadap $\mathrm{Y}$ didapat nilai koefisien korelasi seperti tabel berikut :

Tabel 8 Pengaruh X1 terhadap Y.

Model Summary

\begin{tabular}{|l|r|r|r|r|}
\hline Model & $\mathrm{R}$ & R Square & $\begin{array}{c}\text { Adjusted R } \\
\text { Square }\end{array}$ & \multicolumn{2}{|c|}{ Std. Error of the Estimate } \\
\hline 1 & $.073^{\mathrm{a}}$ & .005 & -.040 & 3.556 \\
\hline
\end{tabular}

a. Predictors: (Constant), ukuran perusahaan

Dari tabel tersebut bahwa koefisien korelasi penyaluran dana modal kerja sebesar 0,73. Besarnya pengaruh ukuran perusahaan terhadap penyaluran dana modal kerja sebesar 0,05 atau 0,5\%.
Begitu pula sebaliknya, korelasi $\mathrm{X} 2$ terhadap Y (Perputaran persediaan terhadap penyaluran dana modal kerja ), hal ini dapat dilihat dari hasil olahan data SPSS seperti tabel berikut :

Tabel 9. Pengaruh X2 terhadap Y

Model Summary

\begin{tabular}{|l|r|r|r|r|}
\hline Model & R & R Square & Adjusted R Square & \multicolumn{1}{|c|}{ Std. Error of the Estimate } \\
\hline 1 & $.147^{\mathrm{a}}$ & .022 & -.023 & 3.526 \\
\hline
\end{tabular}

a. Predictors: (Constant), Perputaran persediaan

Dari tabel tersebut dapat dilihat yang negataip. sebesar $0,2 \%$. Pengaruh ini adalah pengaruh yang kecil. 0,147. Korelasi ini merupakan korelasi 
Tabel 10. Pengarauh (X3) Terhadap Y

\begin{tabular}{|l|rr|r|r|r|}
\hline \multicolumn{1}{|c|}{ Model } & $\mathrm{R}$ & R Square & $\begin{array}{c}\text { Adjusted R } \\
\text { Square }\end{array}$ & Std. Error of the Estimate \\
\hline 1 & $.419^{\mathrm{a}}$ & .176 & .138 & & 3.237 \\
\hline
\end{tabular}

a. Predictors: (Constant), Perputaran piutang

Dari tabel di atas dapat dilihat bahwa korelasi perpuataran piutang terhadap penyaluran dana modal kerja sebesar 0,419. Besarnya pengaruh perputaran piutang terhadap penyaluran dana modal kerja sebesar 0,176 atau sebesar $17,6 \%$.

Koefisien determinasi $\left(\mathbf{R}^{2}\right)$

Tabel 11. Pengaruh secara bersamasama X1, X2, X3 terhadap Y

Model Summary

\begin{tabular}{|l|r|r|r|rr|}
\hline Model & \multicolumn{1}{|c|}{$\mathrm{R}$} & \multicolumn{1}{|c|}{ R Square } & Adjusted R Square & \multicolumn{2}{|c|}{ Std. Error of the Estimate } \\
\hline 1 & $.447^{\mathrm{a}}$ & .200 & .080 & \\
\hline
\end{tabular}

a. Predictors: (Constant), Ukuran perusahaan, Perputaran persediaan, Perputaran piutang

Uji Hipotesis Statistik

$\begin{array}{llrl}\text { 1. Pengujian } & \text { hipotesis } & \text { pertama } & \text { Ho diterima jika Sig.F } \geq 0,05 \text {. Ho ditolak } \\ \text { (Terdapat } & \text { pengaruh } & \text { ukuran } & \text { jika sebaliknya }\end{array}$
perusahaan, perputaran persediaan, perputaran terhadap penyaluran dana modal kerja Hipotesis pertama yang diuji adalah : hipotesis :

Tabel 12. Uji signifikansi regresi berganda.

Membuat kesimpulan kriteria pengujian

\begin{tabular}{|ll|r|r|r|r|r|}
\hline Model & & Sum of Squares & \multicolumn{1}{|c|}{ df } & Mean Square & \multicolumn{1}{c|}{ F } & \multicolumn{1}{c|}{ Sig. } \\
\hline 1 & Regression & 55.907 & 3 & 18.636 & 1.666 & $.020^{\mathrm{a}}$ \\
& Residual & 223.718 & 20 & 11.186 & & \\
& Total & 279.625 & 23 & & & \\
\hline
\end{tabular}

a. Predictors: (Constant), ukuran perusahaan,Perputaran persediaan, perputaran piutang

b. Dependent Variable: Penyaluran dana

Berdasarkan hasil perhitungan di atas, ternyata $\mathrm{F}$ hitung diperoleh sebesar 1,666 atau signifikansi sebesar 0,020 lebih kecil dari $\alpha=0,05$. Oleh karena taraf signifikasni lebih kecil dari 0,05, dengan demikian dapat dikatakan bahwa hipotesis teruji Ho ditolak dan $\mathrm{Ha}$ diterima yang berarti terdapat pengaruh signifikan ukuran perusahaan, perputaran persediaan, dan perputaran piutang terhadap penyaluran dana modal kerja.

2.Pengujian hipotesis kedua (Terdapat pengaruh perputaran persediaan terhadap kepatuhan penyaluran dana modal kerja ).

Berdasarkan hasil uji $\mathrm{t}$ pada tabel hasil out put SPSS didapat harga t hitung sebesar $-0,709$ signifikansi $=-4,86$ yang berarti lebih besar dari $\alpha=0,05$ maka pengaruh perputaran persediaan terhadap penyaluran dana modal kerja adalah tidak berpengaeruh. Dengan demikian dapat dikatakan bahwa hipotesis teruji Ho ditolak dan Ha diterima yang berarti tidak terdapat pengaruh signifikan perputaran persediaan $\left(\mathrm{X}_{2}\right)$ terhadap penyaluran dana modal kerja (Y).

2. Pengujian hipotesis ketiga (Terdapat pengaruh perputaran piutang terhadap penyaluran dana modal kerja ).

Ho: $b_{1}=0$ artinya tidak terdapat pengaruh perputaran piutang (X3) terhadap penyaluran dana modal kerja (Y) 
Ha : $b_{1} \neq 0$ artinya terdapat pengaruh perputaran piutang (X3) terhadap penyaluran dana modal kerja (Y)

Membuat kesimpulan kriteria pengujian hipotesis

Ho diterima jika sig $\mathrm{t} \geq 0,05$

Ha ditolak jika sebaliknya

Berdasarkan hasil uji t pada tabel hasil out put SPSS didapat harga t hitung sebesar -2,046 signifikansi $=0,054$ yang berarti lebih besar dari $\alpha=0,05$ maka pengaruh perputaran piutang terhadap penyaluran dana modal kerja adalah berpengaeruh. Dengan demikian dapat dikatakan bahwa hipotesis teruji Ho ditolak dan Ha diterima yang berarti tidak terdapat pengaruh signifikan perputaran piutang $\left(\mathrm{X}_{2}\right)$ terhadap penyaluran dana modal kerja $(\mathrm{Y})$.

\section{SIMPULAN DAN SARAN \\ 1. Simpulan}

1. Tidak ada pengaruh antara ukuran perusahaan terhadap penyaluran dana modal kerja. Hal ini dapat dilihat dari hasil uji signifikansi yang lebih kecil dari alpa 0,05.

2. Tidak terdapat pengaruh perputaran persediaan terhadap penyaluran dana modal kerja.

3. Ada pengaruh antara perputaran piutang terhadap penyaluran dana modal kerja.

4. Terdapat pengaruh secara bersama-sama ukuran perusahaan, perputaran persediaan, perputaran piutang terhadap penyaluran dana modal kerja. Besarnua pengaruh sebesar $20 \%$.

\section{Saran}

1. Perusahaan untuk terus memperbesar usahanya ke arah yang lebih besar ukuran perusahaannya.

2. Diperlukan pengelolaan persediaan yang optimal, hal ini dikarenakan perputaran persediaan yang tinggi akan dapat mempengaruhi penyaluran dana modal kerja

3. Variabel lain yang dapat mempengaruhi penyaluran dana modal kerja, misalnya Capital adequate Ratio (CAR), Dana pihak ketiga, Non performing loan ataupun tingkat bunga.

\section{E. DAFTAR RUJUKAN}

Amir, Rukmana., Machmud 2010. Bank Syariah : Teori Kebijakan dan Studi Empiris di Indonesia. Erlangga. Jakarta.

Zulkifli. 2007. Panduan Praktis Perbankan Syariah. Zikrul Hakim. Jakarta Timur.

Laksmana, Yusak. 2009. Panduan Praktis Account Officer Bank Syariah. Jakarta: Penerbit Elen Media Komputindo.

Arifin, Zainul. 2007. Manajemen Pengawasan Risiko Pada Bank Syariah. Jakarta.

Bank Mandiri syariah Indonesia. Job Description. Palembang: Kantor Wilayah Sumbagsel

Siamat, Dahlan. 2008. Manajemen Lembaga Keuangan. Jakarta: Lembaga Penerbit Fakultas Ekonomi Universitas Sriwijaya

Sudarsono, Heri. 2008. Bank dan Lembaga Keuangan Syariah Deskripsi dan ilustrasi. Yogyakarta: Penerbit Ekonisia

Munawir. 2014. Analisa Laporan Keuangan. Yogyakarta: Liberty

Kasmir. 2012. Analisis Laporan Keuangan. Rajawali Press: Jakarta.

Sugiyono. 2012. Metode Penelitian Pendidikan Pendekatan Kuantitatif, Kualitatif, dan R\&D. Bandung: ALFABETA. 2012 (cet.15) 